\title{
Communication and Crisis Management in Emergency: A Case Study of Engine's Breakdown
}

\author{
Alfi Dinda Sasantie ${ }^{1}$, Firman Kurniawan ${ }^{2}$ \\ ${ }^{1}$ Magister Ilmu Komunikasi, Universitas Indonesia, Jakarta, Indonesia \\ ${ }^{2}$ Magister Ilmu Komunikasi, Universitas Indonesia, Jakarta, Indonesia \\ alfi.dinda61@ui.ac.id (Alfi Dinda), firman.kurniawan09@ui.ac.id (Firman)
}

\begin{abstract}
The purpose of this study is two-fold: (1) to examine communication of leadership during emergency and (2) to investigate engagement between communication and crisis management to restore organization's objectives. This qualitative study conducted with case study method. The data were collected interview to informant and moderate observation. The study found that one of leader at PT. Bayu Maritim Berkah (BMB) using transactional leadership model and taskoriented style. He also use his power as autocratic. Meanwhile, the communication pattern in BMB during emergency is All-Channel Pattern. The finding of the study shows that BMB used its model and style due to time-efficiency. It also shows that $\mathrm{BMB}$ only perform to respond emergency during the situation and lack of prevention and evaluation.
\end{abstract}

Keywords Communication, Crisis Management, Leadership

\section{Introduction}

Leadership has been defined in many different ways. Referring to Gary A. Yukl (2013: 7) Leadership is the process of influencing others to understand and agree about what needs to be done and how to do it, and the process of facilitating individual and collective efforts to accomplish shared object. It means leader should be able to persuade follower to obey instructions to achieve shared goals.

Referring to its definition shows that leadership is one of the important aspect in organization. In order to achieve organization's objective, leader should be able to communicate well with other to organize and leads. However, leadership of different levels in an organization directly or indirectly determines structural forms, organizational culture and climate, and communications (Men, 2012: 5).

Communication is a value that gather other aspect to connect one to another. Lunenburg and Ornstein (2008) in Lunenburg (2010:2) argue that the structure of an organization should provide for communication in three distinct directions: downward, upward, and horizontal. The communication used by leader to their employee is downward.

On the other hand, organization sometime faces obstacles during achieve their objectives. One of the obstacle is situation that has negative effect and needs to solve quickly to prevent spread the damage, known as emergency. Emergency is situation that can happen unexpectedly and unpredictably. In general, emergency has negative effects which can cause damage or loss to company, other parties or environment. Emergency needs to be addressed effectively, efficiency and quickly. So, the damage and the loss will not spread. Coles (1998); Sylves \& Waugh (1996); And Lindell \& Perry (1995) in Foster (2007: 19) argue that a successful emergency response includes three important factors: leadership, communication, and crisis management.

PT. Bayu Maritim Berkah (BMB) is one of shipping company that support and serve Oil and Gas Industry by providing vessel to conducting its operations. Petronas, as one of BMB's client, has established and leased vessel, named Garuda Emas. This vessel serves as accommodation for the crews who go offshore.

On March 5, 2017, Master Barge of Garuda Emas issued a statement of fact stating that one of Garuda Emas's engine can't be operated. The damage of engine caused operational disruption. As client, Petronas is disserved by this situation. So, they impose downtime on BMB. Downtime is condition which the cost of lease will be borne by vessel's owner, in this matter is BMB. This situation caused losses both of Petronas and BMB.

In sum, the purpose of this paper is two-fold: (1) to examine communication of leadership during emergency and (2) to investigate engagement between communication and crisis management to restore organization's objectives. To be more specifically, this paper analyse the situation during engine's breakdown on Garuda Emas.

\section{Main Body}

Referring to Coles (1998); Sylves \& Waugh (1996); And Lindell \& Perry (1995) in Foster (2007: 19) which states that in order to solve successful emergency situations there are three important factors that are interconnected one to 
another: Leadership, Communication, and Crisis Management. These three factors will be described further and related to the emergency reaction.

\section{Emergency Response}

Based on The Government of Western Australia, Department of Transport, the specifically describes there are six type of marine emergencies. There are: Capsize; Sinking; Grounding; Breakdown; Fire; and Collisions. On BMB's case it inclusive in to Breakdown because one of the Engine could not started.

According to Chao \& Henshaw (2001) emergency situations can be described as an invisible or unexpected situation that could threaten employees, clients, consumers, and / or the public; disrupt company operations; As well as causing physical damage or environmental damage. Emergency situations can be caused by natural disasters as well as human actions. By this understanding, an emergency situation is a condition that negatively impacts both the company, the third party, and the environment. Emergency response is a reaction in organizing, coordinating, and directing existing resources to deal with events and making emergency situations under control (National Institute of Environmental Health Sciences, 2017). To create a successful emergency response, leadership has an important role in organizing, coordinating and directing existing resources to resolve existing emergency situations and prevent the spread of damage.

In emergency situations, uncertainty and panic may increase the extent of damage. Many people become panicked and confused so reluctant to get help. (Foster, 2007: 20). This is where one of the leadership roles in organizing, coordinating, and directing using communication in order to reduce uncertainty. In addition, leaders should also have an emergency response plan to make all efforts undertaken structured so as to reduce the likelihood of confusion in the face of problems and to anticipate the possibility of problems at the initial planning stage.

\section{Leadership in Emergency Response}

James McGregor Burns (1978) distinguishes two types of leadership. First, transactional leadership is those who lead through social exchanges (Bass and Riggio, 2006: 3). While transformational leadership is the leader who seeks to evaluate the wholeness of the followers in line with the goals and objectives of the leader. In addition, leadership style is also divided into two types: Task-Oriented Style and Employee-Oriented Style (Stoner, 1992). According to Kotter (1996) there are eight stages of leadership effort to make changes effectively:

1. Establishing a sense of urgency.

2. Creating the guiding condition.

3. Developing a vision and strategy.

4. Communicating the change vision.

5. Empowering broad-based action

6. Generating short term wins

7. Consolidating gains and producing more change

8. Anchoring new approaches in the culture

\section{Communication in Emergency Response}

According to Bavelas (1950) and Leavitt (1951) in Foster (2007) assessing the positions in communication networks using structural representation to determine the effect of structures in task performance. There are three types of patterns described: Star Pattern, Wheel Pattern and AllChannel Pattern. See Figure 1. The following Communication Patterns:

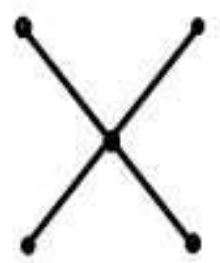

Star Pattern

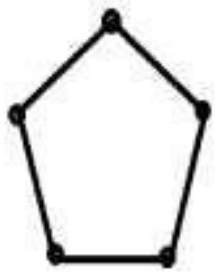

Wheel Pattern

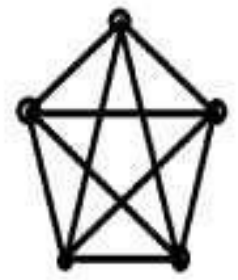

All-Channel Pattern
Figure 1. Communication Patterns

\section{Crisis Management in Emergency Response}

The crisis is divided into three phases: community security, financial loss, and reputation damage. Thus, the organization needs to perform an emergency response to minimize the damage or losses incurred. According to Coombs (2007) Crisis management is a process designed to prevent or reduce the damage that can occur in an organization and other related interests. According to Mitroff (1994) in Boudreaux (2005: 12) crisis of management model is divided into five stages:

1. Signal Detection

This stage focus on warning signs and efforts to prevent crisis.

2. Probing and Prevention

This stage focus on search risk factors and reduce potential for damage.

3. Damage Containment

This stage focus on keep damage spreading to uncontaminated areas.

4. Recovery

This stage focus on return to normal operation as soon as possible.

5. Learning

This stage focus on review, evaluate and critique management effort for improvement.

\section{Research Method}

This qualitative research is conducted by case study as research method. According to Stake (1995) in Creswell (2010: 20) case study is a research strategy in which researchers carefully investigate a program, event, activity, process, or group of individuals. The subject of this research is Head of Department of Procurement and Logistic of PT. Bayu Maritim Berkah. While the object of research that is leadership, communication and crisis management that occurs during emergency situations.

Technique of collecting data is observation and interview. Observations were made using a moderate method in which the researcher was in the study but not involved in all activities performed, only part of the activity. While the interview was conducted on the informant who is the Head of 
Department of Procurement and Logistic at PT. Bayu Maritim Berkah. Selection of informants is based on purposive sampling where the criteria authentic and trustworthy.

Data analysis was done in three ways: analysing artefacts in the form of email, analysing moderate observation, and analysing interview result. However, this study has limited time limits, which does not allow researchers to explore other contributing factors in response to emergency situations.

\section{Result and Discussion}

The results of this research will be categorized into three parts, consisting of: analysing artefacts in the form of email, analysing of moderate observation and analysing interview result. These three sections will be described further as follows:

\section{Analysing Content Email}

The result of analysing content based on email will be shows on Table 1 as follows:

Table 1. The Result of Content Analysis: Email

\begin{tabular}{|c|c|l|}
\hline No & Date & \multicolumn{1}{c|}{ Analysing Content: Email } \\
\hline 1 & May 5,2017 & $\begin{array}{l}\text { - Chief Engineering of Garuda Emas issued } \\
\text { Equipment Defect/Failure and Statement of Fact } \\
\text { which stated that there was the failure of engine } \\
\text { on Garuda Emas. } \\
\text { - Based on EDR, Mr. Ginola contact Engine } \\
\text { Maker (PT. NGT) to explain the situation of } \\
\text { engine. }\end{array}$ \\
\hline 2 & May 6,2017 & $\begin{array}{l}\text { - Mr. Ginola arranges to send the service engineer } \\
\text { to Garuda Emas. } \\
- \text { Mr. Ginola negotiates with PT. NGT regarding } \\
\text { the price for service. }\end{array}$ \\
\hline 3 & May 7,2017 & $\begin{array}{l}\text { - Mr. Ginola instructs staff to generate Purchase } \\
\text { Order } \\
- \text { Service Engineer arrived on Garuda Emas to do } \\
\text { the inspection, however, the issue is beyond } \\
\text { Engine Maker's responsibility. }\end{array}$ \\
\hline 4 & May 8,2017 & $\begin{array}{l}\text { - Mr. Ginola arranges to send PLC Expert to be on } \\
\text { Garuda Emas, he arrived on the same day. } \\
- \text { PLC Expert doing the inspection and the engine } \\
\text { start to runs properly. }\end{array}$ \\
\hline
\end{tabular}

Based on the observation of email content, it shows that Mr. Ginola as Head of Procurement Department took action to contact the Engine Maker which is as reference from EDR given by Chief Master Garuda Emas. However, in fact the damage occurred on the PLC System has nothing to do with Engine Maker. Finally Mr. Ginola took the initiative to contact the PLC Expert. An errors in analysing engine damage resulting in financial losses due to bring in Service Engineer to perform inspections that should be done by BMB Technician. This matter can be prevent if the Chief Engineer of BMB can detect the real problem of the engine. From content analysis of email, it shows that the pattern of communication that occurs is All-Channel Pattern where everyone involved to communicate via email and can read the content of email.

\section{Analysing Moderate Observation}

The result of moderate observation will be shows on Table 2 as follows:
Table 2. The Result of Moderate Observation

\begin{tabular}{|c|c|c|}
\hline No & Date & \multicolumn{1}{c|}{ Analysing Content: Email } \\
\hline 1 & May 5, 2017 & $\begin{array}{l}- \text { Chief Engineering of Garuda Emas performs } \\
\text { standard checking by following instruction of } \\
\text { BMB Technician. }\end{array}$ \\
\hline 2 & May 6,2017 & $\begin{array}{l}\text { - The result, there is some problem on PLC } \\
\text { System. } \\
\text { - Mr. Ginola as per EDR instruct Engine Maker to } \\
\text { inspect the problem. }\end{array}$ \\
\hline 3 & May 7,2017 & $\begin{array}{l}\text { - Service Engineer from PT. NGT arrived on } \\
\text { Garuda Emas. } \\
\text { - Based on inspection, the issue is beyond Engine } \\
\text { Maker's responsibility. }\end{array}$ \\
\hline 4 & May 8,2017 & $\begin{array}{l}\text { - Mr. Ginola arranges to send PLC Expert to be on } \\
\text { Garuda Emas, he arrived on the same day. } \\
\text { PLC Expert doing the inspection and the engine } \\
\text { start to runs properly. }\end{array}$ \\
\hline
\end{tabular}

Based on moderate observation result, Mr. Ginola also involves Procurement Staff on administration. Here it is shown how Mr. Ginola has a task-oriented leadership style to achieve problem solving. The thing that done by Mr. Ginola is giving instruction through email which is including downward communication indirectly because using media, email. This communication is chosen to shorten the time in explaining the situation because the staff can directly learn the situation based on the previous conversations listed on the email.

The results show that this is a fairly effective way because, to reduce the time required to explain the situation. However, the lack of this means of allowing misunderstanding because the interpretation of different people in receiving messages especially with the limited features that exist in the email. In addition, it can be seen that Mr. Ginola's style employs autocratic where all decisions are on the leader without any input from staff.

\section{The Result of Interview}

Based on the interview with Mr. Ginola as Head of the Prolog Department, stated that the first step he made was to contact Engine Maker to see the damage and fix the machine. He made arrangements for the Service Engineer to be in Garuda Emas as soon as possible and Mr. Ginola asked the staff for administration to make the Purchase Order to serve as a contract for the request of the BMB to request the Service Engineer to come to Garuda Emas. Instructions are provided via email by listing previous conversations so staff can read directly the previous conversation. At the time of the emergency situation Mr Ginola focuses on solving the problem so that the crisis is not prolonged. Finally after setting up with Engine Maker and Expert PLC engine can function properly.

Based on the results of interviews, it shows that the crisis management carried out by BMB only at the stage of emergency response only. There is no prevention in emergency situations. Once the problem is solved, the BMB party informs to Garuda Emas that the engine has been able to operate properly. After the situation, BMB did not evaluate related to problem solving. For that the BMB need to do a better management crisis to prevent the occurrence of emergency situations and prevent the spread of damage or losses that could be avoided 


\section{Conclusion}

Based on the above explanation it can be concluded that the role of leadership becomes the important keys in responding emergency situations. However, leadership is related to communication and crisis management. The leadership that carried out by BMB is good enough because the response of emergency situation by using the transactional leadership model and task-oriented leadership style is quite appropriate in solving the problem. However, the crisis management conducted by BMB is only in stage four which is recovery. The process is still not well structured and planned so as to incur additional losses that could be avoided.

\section{ACKNOWLEDGEMENT(S)}

I thank Mr. Firman Kurniawan for his guidance and all things he taught me during this research study. Then, I thank to my family, Mama, Papa, Ekky and also Ben which wholly support and remind me to finish this study. Last, I thank to Bandung Creative Movement Committee to giving me an opportunity to join in this proceeding.

\section{REFERENCES}

[1] Boudreaux, Brian. (2005). Exploring a multi-stage model of crisis management: utilities, hurricanes, and contingency. Florida: University of Florida. http://etd.fcla.edu/UF/UFE0010486/boudreaux_b.pdf

[2] Chao, Elaine L. dan Henshaw, John L. (2001). How to Plan for workplace Emergencies and Evacuations. United State Department of Labor. Access on Thursday, 25 May 2017 time 16.13 site:

https://www.osha.gov/Publications/osha3088.html

[3] Coombs, Timothy. (2007). Crisis Management and Communication. Institute for Public Relation. Access on Wednesday, 24 May 2017 time 14.54 site: http://www.instituteforpr.org/crisis-management-and-comm unications/

[4] Creswell, John W. (2010). Research Design: Pendekatan Kualitatif, kuantitatif, dan Mixed. Yogyakarta: Pustaka Pelajar.

[5] Foster, S. Catherine. (2007). Leadership, Communication, and Conflict Resolution in Emergency Situation: A Case Study of the TOPOFF 2 Exercise. Published Doctor of Philosophy, Capella University.

[6] J.A.F. Stoner, R.E. ve Freeman. (1992). Management (Fift Edition). London: Prentice Hall Internetional, Inc.

[7] Kotter, J. P. (1996). Leading Change. Boston, Mass: Harvard Business School Press.

[8] Lunenburg, Fred C. (2010). Formal communication channels: upward, downward, horizontal, and external. Sam Houston State University: Focus on colleges, universities, and schools. Vol 4 Number 1 https://pdfs.semanticscholar.org/cb0e/c6f253095fa016de05f 882ecf4385f3070e6.pdf
[9] M. B. Bass dan E. G. Riggio. (2006). Transformational Leadership: 2nd Edition. Mahwah, NJ: Lawrance Erlbaum Associatees, 282 pages.

[10] Men, Linjuan. (2012). The effect of organizational leadership on strategic internal communication and employee outcomes. Florida: University of Miami

[11] National Institute of Environmental Health Sciences. (2017). Emergency Response. Access on Thursday, 25 May 2017 time: 16.30 .

https://www.niehs.nih.gov/health/topics/population/response

[12] The Government of Western Australia, Department of Transport. (2017). Type of emergency. Access on Monday, 21 August 2017 time: 21.58. http://www.transport.wa.gov.au/imarine/types-of-emergency .asp

[13] Yukl, Gary A. (2013). Leadership in organizations.. Boston: Pearson Education, Inc. 